\title{
EEF1AKNMT Gene
}

National Cancer Institute

\section{Source}

National Cancer Institute. EEF1AKNMT Gene. NCI Thesaurus. Code C156930.

This gene is involved in both the methylation of translation elong ation factor $1 \mathrm{a}$ and antiapoptotic activity. 